\title{
The Regular Consumption of Nuts Is Associated with a Lower Prevalence of Abdominal Obesity and Metabolic Syndrome in Older People from the North of Spain
}

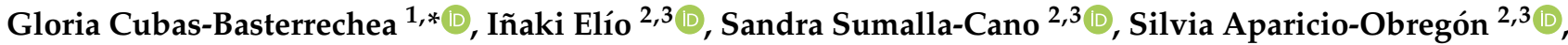 \\ Carolina Teresa González-Antón ${ }^{4}$ and Pedro Muñoz-Cacho ${ }^{5}$ (D)
}

1 Dietetic Section, Hospital Universitario “Marqués de Valdecilla", 39008 Santander, Spain

2 Research Group on Foods, Nutritional Biochemistry and Health, Universidad Europea del Atlántico, 39011 Santander, Spain; inaki.elio@uneatlantico.es (I.E.); sandra.sumalla@uneatlantico.es (S.S.-C.); silvia.aparicio@uneatlantico.es (S.A.-O.)

3 Department of Health, Nutrition and Sport, Iberoamerican Internarional University, Campeche 24560, Mexico

4 NEXO Multidisciplinar Center, Department of Nutrition and Dietetic, 04004 Almeria, Spain; carolinaglan@gmail.com

5 Teaching Department of Primary Care Management, Cantabrian Health Service, IDIVAL, 39011 Santander, Spain; pedro.munoz@scsalud.es

* Correspondence: gcbasterrechea@cofcantabria.org; Tel.: +34-617-597-045

check for updates

Citation: Cubas-Basterrechea, G.; Elío, I.; Sumalla-Cano, S.; Aparicio-Obregón, S.; González-Antón, C.T.; Muñoz-Cacho, P. The Regular Consumption of Nuts Is Associated with a Lower Prevalence of Abdominal Obesity and Metabolic Syndrome in Older People from the North of Spain. Int. J. Environ. Res. Public Health 2022, 19, 1256. https://doi.org/10.3390/ ijerph19031256

Academic Editor: Yasutake Tomata

Received: 18 November 2021

Accepted: 19 January 2022

Published: 23 January 2022

Publisher's Note: MDPI stays neutral with regard to jurisdictional claims in published maps and institutional affiliations.

Copyright: (C) 2022 by the authors. Licensee MDPI, Basel, Switzerland. This article is an open access article distributed under the terms and conditions of the Creative Commons Attribution (CC BY) license (https:// creativecommons.org/licenses/by/ $4.0 /)$.

\begin{abstract}
Background: The aim of this study was to relate the adherence to nut consumption (30 g) three or more days per week to the prevalence of abdominal obesity and metabolic syndrome (MetS) in an elderly population from the north of Spain. Methods: The study consists of an observational, descriptive, cross-sectional, and correlational study conducted in 556 non-institutionalised individuals between 65 and 79 years of age. To define the consumption recommendation of nuts the indication of the questionnaire MEDAS-14 was followed. The diagnosis of MetS was conducted using the International Diabetes Federation (IDF) criteria. Results: In 264 subjects aged 71.9 (SD: \pm 4.2 ) years old, $39 \%$ of whom were men, the adherence to nut consumption recommendations was $40.2 \%$. Of these individuals, $79.5 \%$ had abdominal obesity. The prevalence of MetS was $40.2 \%$, being $47.6 \%$ in men and $35.4 \%$ in women $(p<0.05)$. A nut consumption lower than recommended was associated with a 19\% higher prevalence of abdominal obesity (Prevalence Ratio: 1.19; 95\% CI: $1.03-1.37 ; p<0.05$ ) and a $61 \%$ higher prevalence of MetS (Prevalence Ratio: $1.61 ; 95 \%$ CI: $1.16-2.25 ; p=0.005$ ) compared to a consumption of $\geq 3$ servings per week. Conclusion: An inverse relationship was established between nut consumption and the prevalence of abdominal obesity and metabolic syndrome.
\end{abstract}

Keywords: elderly; nuts; metabolic syndrome X; aging; Spain

\section{Introduction}

The ageing of the global population has acquired significant dimensions, meaning that any issue related to the health of this population has great repercussions. In Spain, according to data from the National Statistics Institute (INE) [1], elderly people (65 years and over) form $19.8 \%$ of the total population. Within Spain, the community of Cantabria is the fifth oldest community in Spain, with a percentage of older people of 22.7\% [1]. In Santander, the capital of Cantabria and the place where the study was carried out, the percentage is even higher, reaching $24.2 \%$ in 2021 [2]. These numbers are sufficiently relevant to propose research studies to improve the public health of this population group.

Achieving greater longevity should be understood not only as the maximum possible length of human life, but it also indicates a higher quality of life in terms of good health [3]. "Healthy ageing", as proposed by the WHO in 2015 [4] is defined as "the process of developing and maintaining the functional capacity that enables well-being in old age". With ageing comes a generalized and progressive deterioration of biological functions, 
a greater vulnerability to the environment and an increased risk of disease and death, with a different rate for each individual $[5,6]$. This is because genetics contributes to $25 \%$ of the changes that occur in ageing (physiological) and the remaining 75\% (epigenetic ageing) of changes due to accumulated diseases and environmental and lifestyle factors, such as diet, which are modifiable [7]. In this regard, there is strong evidence that healthy dietary patterns can modulate atherogenesis directly or through an effect on classical risk factors such as plasma lipids, blood pressure and blood glucose concentration, all of which are associated with MetS [8]. MetS is a set of risk factors associated with abdominal obesity and insulin resistance, characterised by high blood pressure, hyperglycaemia and lipid alterations such as hypertriglyceridemia and lower HDL-c, which will facilitate the development of type 2 diabetes mellitus (DM2) and cardiovascular diseases (CVD) [9]. Nuts are rich in macronutrients and micronutrients that will promote health because they contain a series of bioactive compounds. These include fat-soluble compounds such as unsaturated fats (monounsaturated fatty acids: MUFAs, polyunsaturated fatty acids: PUFAs), tocols (tocopherols and tocotrienols), phytosterols, sphingolipids, carotenoids and chlorophylls, vegetable protein, dietary fibre, water-soluble vitamins (group B), minerals (magnesium, potassium and calcium), and phenolic compounds, which are divided into flavonoids, phenolic acids, stilbenes (resveratrol), hydrolysable tannins (derived from ellagic acid and gallic acid) and condensed tannins, which will be determinant in a series of beneficial biological effects [10-12]. This nutritional composition of nuts makes them of particular interest to older people by improving the quality of their diet, nutritional status [13] and levels of oxidative stress and inflammation [14]. Therefore, the consumption of a healthy diet as part of the Mediterranean diet (rich in vegetables, fruits such as strawberries, virgin olive oil, legumes, white meats, fish and whole grains) in which nuts are regularly included, as a food rich in unsaturated fats replacing foods rich in saturated fats or industrially produced trans fats, is a modifiable factor that can facilitate healthy ageing by reducing the risk of developing pathologies with a high prevalence in this population group, and that are related to cardiovascular diseases such as MetS [15-17] and even associated with psychiatric diseases such as dementia thanks to an improvement in cognitive function [18,19].

The aim of this study was to relate the adherence to nut consumption $(30 \mathrm{~g})$ three or more days per week, with the prevalence of abdominal obesity and metabolic syndrome (MetS) in an elderly population from the north of Spain.

\section{Materials and Methods}

\subsection{Study Design}

This is an observational, descriptive, cross-sectional and correlational study to assess adherence to the recommended consumption of nuts in the elderly population, to determine the prevalence of abdominal obesity and MetS and to analyse whether there is any relationship between them, and also to determine nutritional status through the Body Mass Index (BMI). The scientific-technical validation of the study was obtained from the Primary Care Management of the Cantabrian Health Service (CHS).

\subsection{Participants}

The study population was non-institutionalised elderly people with ages between 65 and 79 years, belonging to the quota of 4 doctors of 3 Primary Care Centres (PCC) in Santander (Cantabria) of the CHS. According to data published by the Cantabrian Institute of Statistics (ICANE) on 28 January 2021, the population with these characteristics amounted to 29,604 individuals [2]. For the calculation of the sample number, a difference of $20 \%$ in the consumption of $\geq 3$ servings of nuts per week was estimated between patients with METs and those without METs and the same between those with abdominal obesity and those without, assuming an alpha risk of $5 \%$ and a beta risk of $20 \%$ in a bilateral contrast. This assumes at least 96 subjects per group, that is, 192 in total. The Granmo v.7.12 program for finite populations [20] was used to calculate the sample. 
To obtain this sample, a three-layer sampling was conducted: firstly, the three PCCs in Santander with the highest number of patients over 65 years of age were chosen; subsequently, a medical quota was chosen from each of the three centres on a purposive basis; that is, it was offered to the coordinator of each of these PCCs and a second medical quota proposed by the PCC coordinator was chosen from the centre that had the highest number of patients in this age group; finally, a random sample of patients stratified by sex and age (65-79 years), chosen by systematic sampling, was selected.

The study started with 556 individuals, of which 239 were ineligible; they were withdrawn by doctors as they met the following exclusion criteria: neurological; psychiatric/psychological pathologies; physical stability problems; mental and cognitive impairment (Pfeiffer test $>4$ errors) [21] and weight change ( $>$ or $<10 \%$ ) in the last 12 months; because they could not be reached by telephone; or because they were unable or unwilling to participate in the study. Of the remaining 317 individuals, there were 53 individuals who were not selected due to missing biochemical blood analysis and/or medication data for the last 12 months for MetS diagnostic parameters according to the International Diabetes Federation (IDF) criteria [22]. Therefore, after random and systematic sampling and after applying the selection and substitution criteria, a final sample of 264 participants (male: $39 \%$ and female: $61 \%$ ) was obtained (Figure 1 ).

Starting number of randomly selected individuals

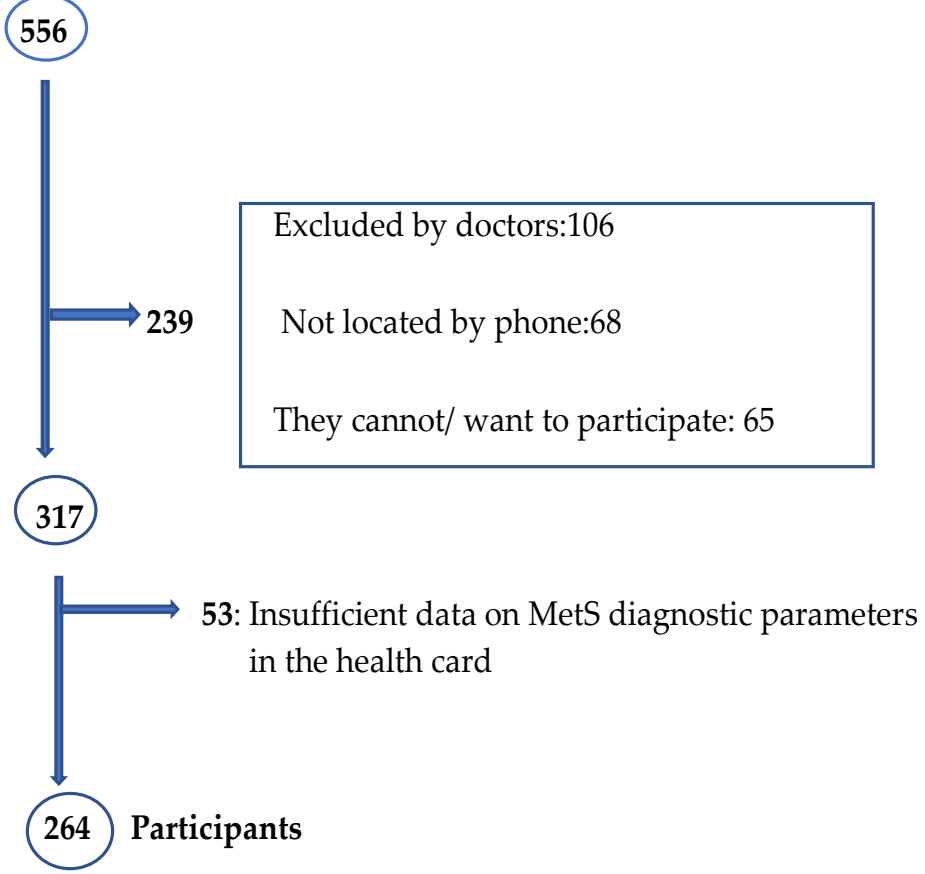

Figure 1. Flow chart of the participant selection process.

\subsection{Sociodemographic Variables}

Sociodemographic characteristics were analysed, including sex, age, marital status, type of cohabitation and level of education. The following three age groups were established: $65-69$ years, 70-74 years and 75-79 years. Marital status included the following four levels: married/partnered, separated, widowed and single. Type of cohabitation was divided into couple, with relatives, with a carer, alone or in a shared flat. Educational level was classified as university, secondary school, primary school and incomplete primary school. 


\subsection{Body Mass Index Levels}

The calculation of the BMI was the result of the quotient between weight and height squared. According to the SEEDO 2000 classification [23], the following 3 levels of nutritional status were established according to their corresponding BMI thresholds: normal weight (18.5-24.9), overweight (25-29.9) and obesity (30-49.9).

\subsection{Diagnosis of Metabolic Syndrome according to IDF Criteria}

To make the diagnosis of MetS, the IDF criteria [22] were used, according to which abdominal obesity is an essential diagnostic parameter (waist circumference for European individuals: $\geq 94 \mathrm{~cm}$ in men and $\geq 80 \mathrm{~cm}$ in women) and also 2 or more of the following parameters must also be present: arterial hypertension $(\geq 130 / 85 \mathrm{mmHg}$, being on treatment or diagnosed), fasting hyperglycaemia $(\geq 100 \mathrm{mg} / \mathrm{dL}$ or previous diagnosis of DM2 or treatment), hypertriglyceridemia ( $\geq 150 \mathrm{mg} / \mathrm{dL}$ or on treatment) and low HDL-c ( $<40 \mathrm{mg} / \mathrm{dL}$ in men and $<50 \mathrm{mg} / \mathrm{dL}$ in women or on treatment).

\subsection{Instruments}

\subsubsection{Adherence to Recommendations for Nut Consumption}

To define the recommendation for nut consumption in older people, the item of the MEDAS-14 questionnaire related to nuts was considered, which recommends consumption of one serving (30 g) 3 or more times a week [24]. Study participants were asked the following question: How many times a week do you consume one serving of nuts (30 g)? The nuts considered in the study included almonds, Brazil nuts, cashews, hazelnuts, pine nuts, pistachios and walnuts.

\subsubsection{Body Mass Index Assessment}

For the determination of the BMI, weight was measured with the SECA ${ }^{\circledR} 711$ scale model (SECA, Hamburg, Germany) Height was measured directly with the SECA ${ }^{\circledR} 220$ stadiometer (SECA, Hamburg, Germany) and the SECA ${ }^{\circledR} 213$ portable model (SECA, Hamburg, Germany), and indirectly by measuring the knee-heel distance, measured with a stadiometer, using the formula of Chumlea et al. that relates age to knee height [25].

\subsubsection{Assessment of Diagnostic Parameters for Metabolic Syndrome}

To measure waist circumference and subsequently assess the presence of abdominal obesity, a SECA model 203 ergonomic tape (SECA, Hamburg, Germany) with millimetric precision was used. For the diagnosis of hypertension, blood pressure was measured with the OMRON M3 comfort ${ }^{\circledR}$ automatic arm blood pressure monitor (Omron, Shimogyo-ku, Kyoto, Japan). The addition of one or more medications for the treatment of hypertension on the health card was also useful. The diagnosis of fasting hyperglycaemia was made based on fasting blood glucose values and prescribed medication for DM2 taken from the health card. Hypertriglyceridemia could be diagnosed through blood triglyceride results and triglyceride medications included in the health card. Low HDL-c was diagnosed using the HDL-c blood data from the health card.

\subsection{Procedure}

To each individual selected, a postal letter was sent from the CHS informing them about the study and a few days later they were called by telephone to request their participation. Once they had accepted, they were summoned to the corresponding PCC and two informed consent forms were handed out (one to be signed by the participant to give consent and the other signed by the researcher, for possible revocation of consent). Afterward, the appropriate procedures were then carried out to obtain the data on adherence to the recommended nut consumption, the prevalence of abdominal obesity and MetS, and the assessment of BMI, as indicated below. 


\subsubsection{Nut Consumption}

The dietician-nutritionists, previously trained, asked the participants in the study the question above mentioned to know about their consumption of nuts, and to facilitate their understanding, they were helped by various portions of nuts or photographs.

\subsubsection{Assessment of Nutritional Status Using BMI}

Anthropometric measurements were taken in the morning, with the individuals barefoot and wearing basic clothing. Two measurements were taken and the mean was calculated. For the weight measurement, the participant was in an erect and relaxed position facing the scale and their eyes were fixed on a horizontal plane. For the height measurement, the height at maximum extension technique was used, with the head in a horizontal position in the Frankfort plane. In the case of spinal pathologies or difficulties in maintaining balance, the distance between the sole of the foot and the upper limit of the patella was measured and the formula created by Chumlea et al. [25] was applied to determine the height in this type of subjects.

\subsubsection{Assessment of Diagnostic Parameters for Metabolic Syndrome}

For the determination of abdominal obesity, the waist circumference (midline between the lower costal margin and the upper edge of the iliac crest, in standing position) was measured [26]. The anatomical reference point was considered to be $2.5 \mathrm{~cm}$ above the umbilicus, as this has been shown in the elderly population to be the best associated with abdominal adipose tissue measured using dual-energy X-ray absorptiometry (DXA) and therefore the best indicator of adipose tissue [27]. Two measurements were performed, and the mean was calculated. If the difference between the two measurements was $>2 \%$, another measurement was performed and the median was taken as valid data [28].

Blood pressure was measured after 2 to 3 min of rest, in a seated position, on the dominant arm. The mean of three measurements was calculated and at least 1 min was allowed to elapse between the two measurements. The rest of the MetS diagnostic parameters were obtained by accessing the biochemical blood analysis and medication data from each individual's CHS health card. Finally, a diagnosis of MetS was made when the waist circumference was greater than the values indicated according to the IDF criteria and at least two of the diagnostic parameters for MetS were also met.

\subsection{Statistical Analysis}

The SPSS 25 software was used to analyse the data (IBM Corp. Released 2017. IBM SPSS Statistics for Windows, Version 25.0 Armonk, NY, USA: IBM Corp.) and Epidat 4.2, July 2016 (Consellería de Sanidade, Xunta de Galicia, Spain).

Qualitative variables were described by calculating frequencies and percentages. To establish the association between an independent variable (consumption of nuts $\geq 3$ servings/week, abdominal obesity, prevalence of MetS) and a dichotomous variable (gender) or more than one category (age groups), the Pearson's chi-square statistical test was performed. If the qualitative variable has several categories that do not have an order (types of nutritional status according to BMI) to compare the results by gender or age groups, the chi-square test of goodness of fit was used, with the Epidat 4.2 program (Consellería de Sanidade, Xunta de Galicia, Spain). If the qualitative variable with several categories has an order (number of variables of diagnosis of MetS), the chi-square test of trend allowed us to calculate if there was any statistically significant difference by gender or age groups in each category.

In the case of quantitative variables, the Kolmogorov-Smirnov $(\mathrm{K}-\mathrm{S})$ non-parametric test of normality was used to determine whether the distribution was normal. The variable with a normal distribution (waist circumference) was described with the mean and standard deviation (SD). To compare two categories (gender) and two independent groups, Student's $t$-test was performed. To compare with more than two categories (age groups), the analysis of variance test (ANOVA) was performed. 
Variables with a non-normal distribution (BMI, number of MetS diagnostic variables) were described with median and interquartile range (IQR). To compare two categories (gender) and two independent groups, the non-parametric Mann-Whitney test was performed. To compare with a variable of more than two categories (age groups) the non-parametric Kruskal-Wallis test was used.

Finally, comparisons between variables were made to look for the possible association between the consumption of nuts adapted to the recommendations and the prevalence of abdominal obesity and MetS. Prevalence ratio (PR) was used as a measure of association and calculated using log-binomial regression.

\section{Results}

\subsection{Adherence to Recommended Nut Consumption}

Of the individuals ( $\mathrm{N}=264), 40.2 \%$ consumed nuts according to the recommendations (one serving between 3 and 7 days a week) and 59.8\% consumed a lower amount. There were no statistically significant differences by sex and age groups, marital status, type of cohabitation and level of education (Table 1).

Table 1. Nut consumption by sociodemographic and health-related variables.

\begin{tabular}{|c|c|c|c|}
\hline & $\begin{array}{c}\text { Low Nut Intake } \\
\text { (<3 Ration/Week) } \\
(\mathbf{N}=158)\end{array}$ & $\begin{array}{l}\text { High Nut Intake } \\
\text { ( } \geq 3 \text { Ration/Week) } \\
\quad(\mathrm{N}=106)\end{array}$ & \\
\hline & $n(\%)$ & $n(\%)$ & $p$-Value ${ }^{1}$ \\
\hline Sex & & & 0.388 \\
\hline Men & $65(63.1)$ & $38(36.9)$ & \\
\hline Women & $93(57.8)$ & $68(42.2)$ & \\
\hline Age groups & & & 0.899 \\
\hline $65-69$ & $51(58.0)$ & $37(42.0)$ & \\
\hline $70-74$ & $60(61.2)$ & $38(38.8)$ & \\
\hline $75-79$ & $47(60.3)$ & $31(39.7)$ & \\
\hline Marital status & & & 0.744 \\
\hline Married/partnered & $97(58.1)$ & $70(41.9)$ & \\
\hline Separated & $9(56.3)$ & $7(43.8)$ & \\
\hline Widowed & $32(66.7)$ & $16(33.3)$ & \\
\hline Single & $20(60.6)$ & $13(39.4)$ & \\
\hline Type of cohabitation & & & 0.803 \\
\hline Couple & $96(58.5)$ & $68(41.5)$ & \\
\hline With relatives & $16(55.2)$ & $13(44.8)$ & \\
\hline With a carer & $2(66.7)$ & $1(33.3)$ & \\
\hline Alone & $43(64.2)$ & $24(35.8)$ & \\
\hline Shared flat & $1(100)$ & $0(0.0)$ & \\
\hline Educational level & & & 0.399 \\
\hline University & $58(54.2)$ & $49(45.8)$ & \\
\hline Secondary school & $47(63.5)$ & $27(36.5)$ & \\
\hline Primary school & $50(65.8)$ & $26(34.2)$ & \\
\hline Incomplete & $3(42.9)$ & $4(57.1)$ & \\
\hline BMI categories & & & 0.035 \\
\hline Normal weight & $31(48.4)$ & $33(51.6)$ & \\
\hline Overweight & $79(59.8)$ & $53(40.2)$ & \\
\hline Obesse & $48(70.6)$ & $20(29.4)$ & \\
\hline
\end{tabular}


Table 1. Cont.

\begin{tabular}{lccc}
\hline & $\begin{array}{c}\text { Low Nut Intake } \\
(<3 \text { Ration/Week }) \\
(\mathbf{N}=\mathbf{1 5 8 )}\end{array}$ & $\begin{array}{c}\text { High Nut Intake } \\
(\geq \mathbf{3} \text { Ration/Week }) \\
\mathbf{( N = 1 0 6 )}\end{array}$ & \\
\hline $\boldsymbol{n ( \% )}$ & $\boldsymbol{n} \mathbf{( \% )}$ & $\boldsymbol{p}$-Value $\mathbf{1}^{\mathbf{1}}$ \\
\hline Health status & & & \\
Hypertension & $128(61.0)$ & $82(39.0)$ & 0.471 \\
Hyperglycemia & $52(61.9)$ & $32(38.1)$ & 0.642 \\
Hipertriglyceridemia & $43(78.2)$ & $12(21.8)$ & 0.002 \\
Los HDL-c & $30(57.7)$ & $22(42.3)$ & 0.723 \\
\hline
\end{tabular}

${ }^{1}$ Differences between low and high nut intake were evaluated using the Pearson Chi square test.

On the other hand, a significant relationship between nut consumption and BMI ranges was observed $(p=0.035)$, with an increase in the prevalence of the consumption of $<3$ servings of nuts per week as the BMI increases: normal weight $(48.4 \%)$, overweight $(59.8 \%$ ) and obese $(70.6 \%)$ ( $p$ for trend: $p=0.010)$. Regarding the relationship between nut consumption and health-related variables, a significant difference $(p=0.002)$ was only observed in the case of individuals diagnosed with hypertriglyceridemia, the prevalence being higher in individuals who consumed $<3$ servings of nuts per week $(78.2 \%)$ compared to those who consumed $\geq 3$ servings per week $(21.8 \%$ ) (Table 1 ).

\subsection{Prevalence of Abdominal Obesity}

The mean waist circumference in men $(\mathrm{N}=103)$ was 102.6 ( $\pm \mathrm{DE}: 10.9)$ and in women $(\mathrm{N}=161)$, it was $90.7( \pm \mathrm{DE}: 13.6)(p<0.001)$. The mean waist circumference values were much higher than the diagnostic values for abdominal obesity $(\geq 94 \mathrm{~cm}$ in men and $\geq 80 \mathrm{~cm}$ in women).

The prevalence of abdominal obesity in the current study was $78.8 \%$; being lower in men $(77.7 \%)$ compared to women $(79.5 \%)$, with no significant difference (Table S1). There were also no significant differences by age group.

\subsection{Prevalence of Nutritional Status according to BMI}

In the sample, $24.2 \%$ were normal weight, $50.0 \%$ overweight and $25.8 \%$ obese $(p=0.001)$. By gender, men had a lower prevalence of normal weight (12.6\%) than women $(31.7 \%)$ $(p<0.001)$. In contrast, men had a higher prevalence of overweight $(60.2 \%)$ compared to women $(43.5 \%)(p<0.01)$ and obesity $(27.2 \%)$ compared to women $(24.8 \%)$, with no significant difference (Table S1). No significant differences were established by age group.

\subsection{Prevalence of Metabolic Syndrome}

As shown in Table S1, the prevalence of MetS was $40.2 \%$. By gender, the prevalence in men $(\mathrm{N}=103)$ was $47.6 \%$ and in women $(\mathrm{N}=161) 35.4 \%$, with a statistically significant difference $(p<0.05)$. The prevalence of MetS varied little between the different age groups, with no statistically significant differences.

The highest prevalence in both sexes was hypertension (79.5\%): $86.4 \%$ in men and $75.2 \%$ in women $(p<0.05)$. The prevalence of hyperglycaemia $(31.8 \%)$ was also higher in men $(45.6 \%)$ compared to women $(23.0 \%)(p<0.001)$. The prevalence of hypertriglyceridemia was much lower $(23.4 \%)$ and similar in men $(20.4 \%)$ and women $(23.6 \%)$. Finally, the prevalence of low HDL-c was $19.7 \%$ (20.4\% in men and $19.3 \%$ in women) (Table S1).

The majority of individuals (38.6\%) had one MetS diagnostic variable other than abdominal obesity. Next, $27.6 \%$ had two diagnostic variables; the percentages of individuals with no or three MetS diagnostic variables were similar (14.4 and $15.2 \%$, respectively). Lastly, the percentage of individuals with four diagnostic parameters was the lowest (4.2\%). There was a significant difference in the percentage of the number of MetS diagnostic variables (hypertension, hyperglycaemia, hypertriglyceridemia, low HDL-c) by gender $(p<0.001)$. Females had a higher percentage of zero or one variable $(19.9$ and $46.0 \%$, 
respectively) compared to males (5.8 and 27.2\%, respectively) ( $p<0.005)$; in contrast, males had a higher percentage of two, three and four MetS diagnostic variables (35.9, 22.3 and $8.7 \%$, respectively) compared to females $(22.4,10.6$ and $1.2 \%$, respectively) respectively (Table S2).

As shown in Table 2, the prevalence of MetS increases with BMI $(p<0.001)$. By gender, the prevalence of MetS in men was higher at all the BMI levels compared to women, with the difference being significant in normal weight and obesity.

Table 2. Prevalence of metabolic syndrome by BMI and gender.

\begin{tabular}{|c|c|c|c|c|}
\hline \multirow[t]{2}{*}{ BMI } & $\begin{array}{c}\text { Men } \\
(N=103)\end{array}$ & $\begin{array}{c}\text { Women } \\
(N=161)\end{array}$ & $p$-Value ${ }^{1}$ & $\begin{array}{c}\text { Total } p \text {-Value }{ }^{2} \\
\quad(\mathrm{~N}=264)\end{array}$ \\
\hline & $n(\%)$ & $n(\%)$ & & $n(\%)$ \\
\hline Normal weight & $4(30.8)$ & $7(13.7)$ & $<0.001$ & $11(17.2)$ \\
\hline Overweight & $25(40.3)$ & $27(38.6)$ & 0.783 & $52(39.4)$ \\
\hline Obesity & $20(71.4)$ & $23(57.5)$ & 0.023 & $43(63.2)$ \\
\hline
\end{tabular}

${ }^{1}$ Differences between gender were evaluated using the Pearson Chi square Goodness-of-Ft test; ${ }^{2}$ Chi square trend: $<0.001$.

\subsection{Association between the Adherence to Recommended Nut Consumption and Prevalence of Abdominal Obesity}

The individuals who consumed one serving (30 g) of nuts three or more times a week had a prevalence of abdominal obesity of $70.8 \%$, compared to the consumers of nuts less than three times a week which had a $13.4 \%$ higher prevalence of abdominal obesity $(84.2 \%)$ $(p<0.01)$.

In addition, it was found that the proportion of people with abdominal obesity was $19 \%$ higher among those who consumed a portion of nuts less than three times a week compared to those who consumed nuts three or more times a week (PR: 1.19; 95\% CI: $1.03-1.37 ; p<0.05)$ (Table 3).

Table 3. Association between nut consumption and abdominal obesity and metabolic syndrome.

\begin{tabular}{|c|c|c|c|c|}
\hline & $\begin{array}{c}\text { Low Nut Intake } \\
\text { (<3 Ration/Week) } \\
\quad(\mathbf{N}=158)\end{array}$ & $\begin{array}{l}\text { High Nut Intake } \\
(\geq 3 \text { Ration/Week) } \\
\quad(\mathrm{N}=106)\end{array}$ & & \\
\hline & $n(\%)$ & $n(\%)$ & PR; (95\% IC) & $p$-Value ${ }^{1}$ \\
\hline Abdominal obesity & $133(84.2)$ & $75(70.8)$ & $1.19(1.03-1.37)$ & 0.015 \\
\hline Metabolic syndrome & $74(46.8)$ & $32(30.2)$ & $1.61(1.16-2.25)$ & 0.005 \\
\hline
\end{tabular}

${ }^{1}$ Wald chi-square. PR: prevalence ratio. IC: $95 \%$ confidence interval.

\subsection{Association between Adherence to the Recommended Consumption of Nuts and Prevalence of Metabolic Syndrome}

The individuals who consumed one serving (30 g) of nuts three or more times a week had a prevalence of MetS of $30.2 \%$, compared to the consumers of nuts less than three times a week which had a $16.6 \%$ higher prevalence of METs $(46.8 \%)(p<0.01)$.

It was also found that the proportion of people with MetS was 61\% higher among those who consumed a portion of nuts less than three times a week compared to those who consumed nuts three or more times a week (PR: 1.61 ; 95\% CI: 1.16-2.25; $p=0.005$ ) (Table 3).

\section{Discussion}

\subsection{Adherence to Recommended Nut Consumption}

Nuts stand out for being the second food, after olive oil, that provides unsaturated fatty acids (MUFAs and PUFAs) with anti-inflammatory and vaso-protective activity [29]. Omega-3 fatty acids are a family of essential and biologically relevant fatty acids that belong to the PUFAs, being mostly available in nuts, alfa-linolenic acid (ALA), which is 
metabolised to eicosapentaenoic acid and docosahexaenoic acid, with anti-inflammatory properties. In this regard, a recent meta-analysis published in 2021 by Naghshi et al. [30] found that a high intake of ALA was associated with a reduced risk of mortality from all causes, CVD and coronary heart diseases. Additionally, the nuts contain phytosterols, which have an inverse relationship with blood cholesterol levels [31] and other bioactive compounds with antioxidant properties such as polyphenols and vitamin E, all of which play an important role in the prevention of cardiovascular disease [32]. Moreover, ageing is associated with oxidative damage and a pro-inflammatory state; therefore, age can be considered a risk factor for CVD $[33,34]$. In this regard, it has been shown that regular nut consumption is associated with reductions in some, but not all, markers of oxidative stress and inflammation [14]. However, only $40.2 \%$ of the elderly participants in the study consumed three or more servings (30 g) of nuts per week; there were no significant differences in consumption according to the different socio-demographic variables studied (sex, age groups, marital status, type of cohabitation and level of education) (Table 1). However, a significant association was observed by increasing the prevalence of the consumption of $<3$ servings per week of nuts with an increasing BMI ( $p$ of trend: 0.010 ) (Table 1), which seems to indicate that, especially in overweight and obese elderly people, the consumption of nuts was mainly less frequent than recommended, and thus decreasing the adherence to the Mediterranean diet. A possible reason for this low nut consumption is the belief in the older population that the composition of nuts, rich in fatty acids, is associated with weight gain. However, a systematic review and meta-analysis of prospective cohorts and randomized controlled trials published in 2021 [35] evaluating the impact of nut consumption on adiposity measures concluded that, based on current evidence, health professionals and dietary guidelines can advise a daily consumption of a $42.5 \mathrm{~g}$ serving, except for people with nut allergies, without an increase in adiposity or concern for an adverse on body weight control. According to previous studies carried out in other populations in the Mediterranean basin, it seems that a lower than recommended consumption of nuts is common in older people, since in a recent study [36], in individuals aged 60-69 years, the percentage of adherence to the recommendations was $34 \%$ and in individuals aged $70-79$ years it was 32\%, and on the other hand, in a population aged over 65 years living in Sicily, the percentage of individuals with a low consumption of nuts (average $4.3 \mathrm{~g} /$ day) was significantly higher (21.9\%) than those with a high nut consumption (mean $39.7 \mathrm{~g} /$ day), which stood at $16.4 \%(p=0.004)$ [37]. The low consumption of nuts obtained in the study coincides with the results of the Spanish Food Consumption Report [38], as Cantabria is the second community with the lowest consumption of this type of food, with a consumption below the average (3.35 kg/person/year).

Another possible reason for the low consumption of nuts in elderly people may be related to chewing problems and dysphagia that are very common in this population group, however, should facilitate the daily consumption of small amounts (between 28.3 to $42.5 \mathrm{~g}$ ) [35], through techniques such as crushing and incorporating them into foods that are easy to chew and swallow such as yogurts. In this way, the population mentioned before will take advantage of the beneficial properties demonstrated in the PREDIMED study [39], according to which the consumption of a Mediterranean diet supplemented with $45 \mathrm{~g}$ of nuts daily in an elderly population at high cardiovascular risk reduced the risk of myocardial infarction and cerebrovascular infarction and mortality from these pathologies by up to $30 \%$, associated with improvements in the components of MetS.

\subsection{Prevalence of the Metabolic Syndrome}

The prevalence of MetS, according to the IDF criteria [22], was 40.2\%. This prevalence resembles that obtained for the Spanish population over 65 years of age in the ENRICA study with 42.3\% [40] and is quite distant from that obtained in other parts of the world: Mexico (72.9\%) [41], United States (54.9 $\pm 1.7 \%$ ) [42], Iran (51.7\%) [43] and Russia $(34.7 \%)[44]$. 
In the HERMEX study [45], the prevalence in individuals aged 65-74 years was 59.6\% and in those aged $75-79$ years it was $64.8 \%$, increasing with age. It is common for the prevalence of MetS to be higher with increasing age because, as it is associated with the ageing process, the prevalence of the number of components of MetS tends to increase. However, in the current study, no significant differences were observed in the prevalence of MetS by age group; but differences by gender were observed.

The prevalence of MetS obtained was higher in men than in women (47.6\% vs. 35.4\%) $(p<0.05)$. These results contrast with a large majority of studies, obtained using different methods of diagnosing MetS, carried out in various countries worldwide in the elderly population, in which the prevalence obtained was higher in women: in Korea [46]: 50\% vs. $36.4 \%$; in China [47]: $47.55 \%$ vs. $39.74 \%$; in India [48]: $50.9 \%$ vs. $34.4 \%$; in Ecuador [49]: $66.9 \%$ vs. $47.9 \%$; in Brazil [50]: $65.6 \%$ vs. $60.3 \%$; in Russia [44]: $41.7 \%$ vs. $26.8 \%$; in Portugal [51]: $40 \%$ vs. $22 \%$; in Finland [52]: $47.8 \%$ vs. $37.2 \%$; in Mediterranean islands (Malta, Cyprus and Greece) [53]: 35\% vs. 24\%; and in Spain in the DARIOS study [54]: $52.5 \%$ vs. $42.2 \%$, the ENRICA study [40]: $44.5 \%$ vs. $39.5 \%$ and in the HERMEX study [45]. However, in other studies the prevalence in older people was higher in men, such as in the Mexican population where the prevalence was $75.7 \%$ in men and $70.4 \%$ in women [41], in France with ages between 55-74 years (40.3\% vs. 34.4\%) with no significant difference [55] and in the Dutch population taking into account sex, age and BMI together [56].

The higher prevalence of MetS in men obtained in the study does not seem to be related to the accumulation of android fat, with a higher prevalence of abdominal obesity, as there were no statistically significant differences by sex in this parameter, although in both sexes it was high and higher in women (79. 5\% vs. 77.7\%), coinciding with the results of the ENRICA study [40], in which the prevalence of abdominal obesity is higher in women $(94.2 \%)$ than in men $(82.4 \%)$, due to the fact that central adiposity is very common in women after menopause [57]. The high prevalence of abdominal obesity in older women is due to the fact that at this stage of life the decrease in estrogen levels leads to the hypertrophy of adipocytes and a rapid increase in visceral adipose tissue, which is associated with insulin resistance and an inflammatory and prothrombotic state [58].

The higher prevalence of MetS in men could be related to differences in BMI (Table S1); as men had a higher prevalence of overweight $(60.2 \%)$ compared to women $(43.5 \%)$ $(p<0.01)$, a similar but higher prevalence of obesity in men $(27.2 \%$ vs. $24.8 \%)$ and a lower prevalence of normal weight in men $(12.6 \%$ vs. $31.7 \%)(p<0.001)$. All of this linked with a high prevalence of abdominal obesity in men $(77.7 \%)$, will facilitate adipose tissue dysfunction and insulin resistance and the development of metabolic comorbidities and, therefore, a higher prevalence of MetS [59] and CVD.

However, it was found that although the prevalence of MetS increases with BMI for both sexes, the prevalence of MetS in normal weight and obese men was significantly higher than in women (Table 2). In this way, it was shown that MetS was $84 \%$ more frequent in men than in women (PR: $1.84 ; 95 \%$ CI: $1.39-2.45 ; p<0.001)$.

Therefore, it seems that not only factors related to BMI are involved in the higher prevalence of METs in men, associated with men with a higher percentage of two, three and four diagnostic variables compared to women (Table S2), other known factors involved in the development of METs should also be considered. It is recognized that the increasing prevalence of MetS in older people is influenced by age, as well as by gender, by an altered testosterone/estrogen balance [56], and also by various factors such as the consumption of an unhealthy diet; overweight-obesity; a sedentary lifestyle (smoking, stress, alcoholism); socio-economic aspects (culture-education, economic level) [60]; social relationships, since if a friend, sibling or partner is obese, the likelihood of an individual being obese increases [61]; place of residence, whether rural or urban [51]; and even pathologies such as depression, often associated with ageing, can be affected by being associated with obesity, an unhealthy diet and physical inactivity [62]. All of these factors may affect individuals and men and women differently and may determine gender differences in the prevalence of MetS. 


\subsection{Relationship between Adherence to Recommended Nut Consumption and Prevalence of Abdominal Obesity and Metabolic Syndrome}

The study found that the consumption of a portion of nuts $<3$ times per week was associated with a $19 \%$ higher prevalence of abdominal obesity and a $61 \%$ higher prevalence of MetS compared to consumption $\geq 3$ times a week.

Since this is an observational study, no causal relationship can be extracted. However, there are recent longitudinal studies that confirm the benefits of regular nut consumption. Thus, in the PREDIMED study, conducted in older people at cardiovascular risk, it was shown that the consumption of more than three servings of nuts per week was associated with a 32 and $26 \%$ lower prevalence of abdominal obesity and MetS, respectively, compared to those who did not consume nuts [63]. Similar results were obtained in the University of Navarra follow-up study (SUN) [64] in which women who consumed more than two servings of nuts per week had a lower risk of MetS compared to those who consumed less. Even in countries outside the Mediterranean basin, there has been interest in the influence of nut consumption, particularly walnuts, on the development of MetS. According to Hosseinpour-Niazi et al. [65], the consumption of $\geq 5$ servings/week of walnuts reduced the incidence of MetS compared to when consumption was $\leq 1$ serving/week (OR: 0.68, 95\% CI: $0.44-0.91, p$ for trend:0.03). Furthermore, for each additional serving consumed per week, the incidence of MetS decreased by 3\%. Additionally, in another study by Hassannejad et al. [66], it was concluded that the regular consumption of nuts was negatively associated with the severity and risk of developing MetS.

These results are associated with the beneficial effects of nut composition on various parameters related to metabolic syndrome. In this regard, daily consumption of nuts over 5 years of follow-up has been observed to reduce waist circumference gain and decrease body weight [67], related to their satiating effect, incomplete digestion in the gut and lower amount of metabolizable energy. In addition, nuts appear to have a preventive effect on the development of overweight/obesity, despite what might be assumed from their fatty acidrich nutritional composition, as individuals who consume nuts frequently tend to eat less red meat and processed meat, facilitating adherence to a healthy diet [68]. A meta-analysis of prospective studies [69] showed a 15\% reduction in the risk of high blood pressure when comparing extreme nut consumption $(0-37 \mathrm{~g} /$ day), which is possibly associated with a reduction in inflammation and an improvement in the endothelial dysfunction attributable to their composition (rich in L-arginine, MUFAs, PUFAs, polyphenols and non-sodium minerals). Additionally, a recent study [37] showed an inverse association between high nut consumption (mean $39.7 \mathrm{~g} /$ day) and lower odds of high blood pressure $(\mathrm{OR}=0.61$, 95\% CI: 0.46-0.80). Furthermore, the reduction in hypertension through regular nut intake has a biological explanation, as it implies a lower risk of body adiposity, as indicated above and the fact that $75 \%$ of the incidence of hypertension is related to obesity [70]. In a metaanalysis of 61 randomized controlled trials [71], it was found that a daily consumption of nuts shows a reduction in the blood levels of total cholesterol, LDL-c and triglycerides, but has no effect on HDL-c levels, which are more associated with the frequency and number of servings consumed rather than the type of nut. In the present study, it was also found that the prevalence of hypertriglyceridemia was lower in individuals who consumed $\geq 3$ servings of nuts per week $(21.8 \%)$ compared to those who consumed $<3$ servings per week $(78.2 \%)(p=0.002)$. Additionally, the composition of nuts that are rich in PUFAs, a dietary fibre that delays gastric emptying, reduces intestinal absorption and increases satiety; and components such as ellagic acid with anti-inflammatory and anti-oxidative properties, explains the greater glycaemic control and lower incidence of DM2 [72]. Nuts are one of the most important sources of omega- 3 fatty acids. In this regard, a meta-analysis of 45 clinical trials found that supplementation with omega-3 fatty acids was associated with improved lipid profile, inflammation, and glycaemia in people with diabetes [73].

The results obtained, being an observational study with a small number of individuals, have their limitations, particularly in terms of being able to draw cause-effect conclusions. It is necessary to add as a limitation in this study that the association of nut consumption 
with abdominal obesity and METs has not been controlled for possible confounding variables. Finally, another limitation is that no other biochemical, somatometric or nutritional variables have been quantified, apart from those indicated in the study, which could be related to abdominal obesity and METs.

\section{Conclusions}

Given the beneficial association between consuming a serving of nuts three or more times per week and a lower prevalence of abdominal obesity and MetS, dietary recommendations to increase nut consumption in older people would be advisable and public health nutrition programs should implement the intake of nuts as a part of a healthy diet in the elderly population.

Further cross-sectional and longitudinal research related to nut consumption in older people should be conducted in larger communities, and in elderly populations living independently and in institutions.

Supplementary Materials: The following supporting information can be downloaded at: https: / / www.mdpi.com/article/10.3390/ijerph19031256/s1, Table S1. Prevalence of BMI, metabolic syndrome, and its components by gender; Table S2. Percentage of number of variables diagnosing metabolic syndrome, (hypertension, hyperglycaemia, hypertriglyceridemia and low HDL-c) by gender.

Author Contributions: Conceptualization and methodology, G.C.-B., C.T.G.-A. and P.M.-C.; software, G.C.-B. and P.M.-C.; validation, G.C.-B. and P.M.-C.; formal analysis, G.C.-B. and P.M.-C.; investigation, G.C.-B., I.E., S.S.-C., S.A.-O., C.T.G.-A. and P.M.-C.; resources, G.C.-B., I.E. and P.M.-C.; data curation, G.C.-B. and P.M.-C.; writing-original draft preparation, G.C.-B., I.E. and C.T.G.-A.; writing-review and editing, G.C.-B., I.E., S.S.-C. and S.A.-O.; visualization, G.C.-B., I.E., S.S.-C., S.A.-O., C.T.G.-A. and P.M.-C.; supervision, G.C.-B., I.E., S.S.-C., S.A.-O., C.T.G.-A. and P.M.-C.; project administration, G.C.-B. All authors have read and agreed to the published version of manuscript.

Funding: This research received no external funding.

Institutional Review Board Statement: The study was conducted according to the guidelines of the Declaration of Helsinki and approved by the Ethics Committee of Universidad Internacional Iberoamericana (UNINI) (México) (CR-10/2018, 19/10/2018) and Valdecilla Institute for Health Research (IDIVAL) (2018-308, 04/2019) of the Cantabrian Health Service (CHS).

Informed Consent Statement: Informed consent was obtained from all subjects involved in the study. The data protection and digital rights rules set out in Regulation (EU) 2016/679 and Organic Law 3/2018 were followed.

Data Availability Statement: The data presented in this study are available on request from the corresponding author.

Acknowledgments: To primary care physicians of the Health Centers (HC) of Santander who carried out the selection of participants following the exclusion criteria: Guzmán Alonso (Vargas HC), Óscar Puente (Centro HC), José Antonio Otero and José Antonio Gutiérrez Bardeci (both from Puertochico $\mathrm{HC}$ ). To the European Atlantic University for providing trainee dieticians-nutritionists to carry out the fieldwork. Additionally, to the dietitians-nutritionists: Carmen de la Vega-Hazas, Irene Doporto and Jesús Puente. To Álvaro Macías and Beatríz Macías for their contribution to the English translation of the article. Additionally, of course, to all the people who voluntarily decided to participate in the study.

Conflicts of Interest: The authors declare no conflict of interest.

\section{References}

1. Instituto Nacional de Estadística (INE). Proporción de Personas Mayores de Cierta de Edad por Provincia [Database on the Internet]; INE: Madrid, Spain, 2021. Available online: https:/ / www.ine.es/jaxiT3/Tabla.htm?t=1488 (accessed on 30 September 2021).

2. Instituto Cántabro de Estadística (ICANE). Padrón Municipal de Habitantes de 2020: Por Grupos Quinquenales y Sexo [Database on the Internet]; ICANE: Santander, Spain, 28 January 2021. Available online: https:/ /www.icane.es/data/municipal-registerquinquennial-age-group-gender\#timeseries (accessed on 1 September 2021). 
3. Daengtern, L.; Thojampa, S.; Kumpeera, K.; Wannapornsiri, C.; Boonpracom, R. Factors affecting quality of life and longevity in the elderly people in Phrae city, Thailand. Asian Pac. Isl. Nurs. J. 2020, 5, 48-54. [CrossRef]

4. Organización Mundial de la Salud (OMS). Informe Mundial Sobre el Envejecimiento y la Salud [Monograph on the Internet]; OMS: Ginebra, Switzerland, 2015; Available online: https://apps.who.int/iris/bitstream/handle/10665/186471/WHO_FWC_ALC_15 .01_spa.pdf\%3Bjsessionid=58559B079FC2220A8FE6767E9BE0DEF2? sequence=1 (accessed on 27 November 2021).

5. Organización Mundial de la Salud. Envejecimiento y Salud [Monograph on the Internet]; OMS: Ginebra, Switzerland, 2018; Available online: http:/ /www.who.int/es/news-room/fact-sheets/detail/envejecimiento-y-salud (accessed on 4 October 2021).

6. Organización Mundial de la Salud [Web Site]. Organismos Internacionales y Envejecimiento; OMS: Ginebra, Switzerland, 2009; Available online: http:/ / traballoxunta.es/export/sites/default/Biblioteca/Documentos/Publicacions/congreso_envellecemento/ congreso-envejecimiento_activo.pdf. (accessed on 15 November 2021).

7. Ribera, J.M. Microbiota intestinal y envejecimiento: ¿un nuevo camino de intervención? Rev. Española Geriatr. Gerontol. 2016, 51, 290-295. [CrossRef] [PubMed]

8. Catapano, A.L.; Graham, I.; De Backer, G.; Wiklund, O.; Chapman, M.J.; Drexel, H.; Hoes, A.W.; Jenning, C.S.; Landmesser, U.; Pedersen, T.R.; et al. 2016 ESC/EAS guidelines for the management of dyslipidaemias. Rev. Española Cardiol. 2017, 70, 115.e1-115.e64. [CrossRef]

9. Gurka, M.J.; Guo, Y.; Filipp, S.L.; DeBoer, M.D. Metabolic syndrome severity is significantly associated with future coronary heart disease in type 2 diabetes. Cardiovasc. Diabetol. 2018, 17, 17-25. [CrossRef] [PubMed]

10. Alasalvar, C.; Salas-Salvadó, J.; Ros, E. Bioactives and health benefits of nuts and dried fruits. Food Chem. 2020, $314,126192$. [CrossRef] [PubMed]

11. Alasalvar, C.; Chang, S.K.; Shahidi, F. Nuts: Nutrients, natural antioxidants, fat-soluble bioactives, and phenolics. In Health Benefits of Nuts and Dried Fruits, 1st ed.; Alasalvar, C., Salas-Salvadó, J., Ros, E., Sabaté, J., Eds.; CRC Press: Boca Raton, FL, USA, 2020; pp. 13-57. [CrossRef]

12. Lainas, K.; Alasalvar, C.; Bolling, B.W. Effects of roasting on proanthocyanidins contents of Turkish Tombul hazelnut and its skin. J. Funct. Foods 2016, 23, 647-653. [CrossRef]

13. Tan, S.Y.; Tey, S.L.; Brown, R. Can nuts mitigate malnutrition in older adults? A conceptual framework. Nutrients 2018, 10, 1448. [CrossRef]

14. Neale, E.P.; Tapsell, L.C.; Guan, V.; Batterham, M.J. The effect of nut consumption on markers of inflammation and endothelial function: A systematic review and meta-analysis of randomized controlled trials. BMJ Open 2017, 7, e016863-1-e016863-14. [CrossRef]

15. Forouhi, N.G.; Krauss, R.M.; Taubes, G.; Willett, W. Dietary fat and cardiometabolic health: Evidence, controversies, and consensus for guidance. BMJ 2018, 361, k2139. [CrossRef]

16. Forbes-Hernandez, T.Y.; Gasparrini, M.; Afrin, S.; Bompadre, S.; Mezzetti, B.; Quiles, J.L.; Giampieri, F.; Battino, M. The healthy effects of strawberry polyphenols: Which strategy behind antioxidant capacity? Crit. Rev. Food Sci. Nutr. 2016, 56, S46-S59. [CrossRef]

17. Zhang, Y.; Zhang, D.Z. Relationship between nut consumption and metabolic syndrome: A meta-analysis of observational studies. J. Am. Coll. Nutr. 2019, 38, 499-505. [CrossRef] [PubMed]

18. Martínez-Lapiscina, E.H.; Clavero, P.; Toledo, E.; Estruch, R.; Salas-Salvadó, J.; San Julian, B.; Sánchez-Tainta, A.; Ros, C.; Valls-Pedret, C.; Martínez-González, M.A. Mediterranean diet improves cognition: The PREDIMED-NAVARRA randomised trial. J. Neurol. Neurosurg. Psychiatry 2013, 84, 1318-1325. [CrossRef] [PubMed]

19. Pistollato, F.; Iglesias, R.C.; Ruíz, R.; Aparicio, S.; Crespo, J.; Lopez, L.D.; Manna, P.P.; Giampieri, F.; Maurizio, B. Nutritional patterns associated with the maintenance of neurocognitive functions and the risk of dementia and Alzheimer's disease: A focus on human studies. Pharmacol. Res. 2018, 131, 32-43. [CrossRef] [PubMed]

20. Institut Hospital del Mar d'Investigacions Médiques (IMIM) [Web Site]. IMIM-Hospital del Mar: Barcelona, Spain, 2012. Available online: https:/ /imim.cat/ofertadeserveis/software-public/granmo/ (accessed on 25 December 2021).

21. Martínez de la Iglesia, J.; Dueñas Herrero, R.; Onís Vilches, M.C.; Aguado Taberné, C.; Albert Colomer, C.; Luque Luque, R. Adaptación y validación al castellano del cuestionario de Pfeiffer (SPMSQ) para detectar la existencia de deterioro cognitivo en personas mayores de 65 años. Med. Clin. 2001, 117, 129-134. [CrossRef]

22. International Diabetes Federation. The IDF Consensus Worldwide Definition of Metabolic Syndrome [Monograph on Internet]; IDF: Brussels, Belgium, 2005; Available online: https://www.pitt.edu/ \{\}super1/Metabolic/IDF1.pdf (accessed on 24 December 2021)

23. Sociedad Española para el Estudio de la Obesidad (SEEDO). Consenso SEEDO'2000 para la evaluación del sobrepeso y la obesidad y el establecimiento de criterios de intervención terapéutica. Med. Clin. 2000, 115, 587-597. [CrossRef]

24. Schröder, H.; Fitó, M.; Estruch, R.; Martínez-González, M.A.; Corella, D.; Salas-Salvadó, J.; Lamuela-Raventós, R.; Ros, E.; Salaverría, I.; Fiol, M.; et al. A short screener is valid for assessing mediterranean diet adherence among older spanish men and women. J. Nutr. 2011, 141, 1140-1145. [CrossRef]

25. Chumlea, W.; Roche, A.; Steinbaugh, M. Estimating stature from knee height for persons 60 to 90 years of age. J. Am. Geriatr. Soc. 1985, 33, 116-120. [CrossRef] 
26. World Health Organization (WHO). Obesity: Preventing and Managing the Global Epidemic: Report of a WHO Consultation; WHO Technical Report Series 894; World Health Organization: Geneva, Switzerland, 2000; Available online: https://apps.who.int/iris/ handle/10665/42330 (accessed on 15 October 2021).

27. Guerra, R.S.; Amaral, T.F.; Marques, E.A.; Mota, J.; Restivo, M.T. Anatomical location for waist circumference measurement in older adults: A preliminary study. Nutr. Hosp. 2012, 27, 1554-1561. [CrossRef]

28. Sociedad Internacional para el Avance de la Kinantropometría. Estándares Internacionales Para la Valoración Antropométrica; Universidad Católica San Antonio de Murcia: Murcia, Spain, 2001.

29. Silveira, B.K.S.; da Silva, A.; Hermsdorff, H.H.M.; Bressan, J. Effect of chronic consumption of nuts on oxidative stress: Systematic review of clinical trials. Crit. Rev. Food Sci. Nutr. 2020, 12, 1-12. [CrossRef]

30. Naghshi, S.; Aune, D.; Beyene, J.; Mobarak, S.; Asadi, M.; Sadeghi, O. Dietary intake and biomarkers of alpha linolenic acid and risk of all cause, cardiovascular, and cancer mortality: A systematic review and dose-response meta-analysis of cohort studies. BMJ 2021, 375, n2213. [CrossRef]

31. Escurriol, V.; Cofan, M.; Serra, M.; Bulo, M.; Basora, J.; Salas-Salvadó, J.; Corella, D.; Zazpe, I.; Martínez-González, M.A.; Ruíz-Gutiérre, V.; et al. Serum sterol responses to increasing plant sterol intake from natural foods in the Mediterranean diet. Eur. J. Nutr. 2009, 48, 373-382. [CrossRef] [PubMed]

32. Rusu, M.E.; Simedrea, R.; Gheldiu, A.M.; Mocan, A.; Vlase, L.; Popa, D.S.; Ferreira, I.C.F.R. Benefits of tree nut consumption on aging and age-related diseases: Mechanisms of actions. Trends Food Sci. Technol. 2019, 88, 104-120. [CrossRef]

33. López-Otín, C.; Blasco, M.A.; Partridge, L.; Serrano, M.; Kroemer, G. The hallmarks of aging. Cell 2013, 153, 1194-1217. [CrossRef] [PubMed]

34. Battino, M.; Forbes-Hernández, T.Y.; Gasparrini, M.; Afrin, S.; Cianciosi, D.; Zhang, J.; Manna, P.P.; Rebordo-Rodríguez, P.; Varela López, A.; Quiles, J.L.; et al. Relevance of functional foods in the Mediterranean diet: The role of olive oil, berries and honey in the prevention of cancer and cardiovascular diseases. Crit. Rev. Food Sci. Nutr. 2019, 59, 893-920. [CrossRef] [PubMed]

35. Nishi, S.K.; Viguiiouk, E.; Blanco Mejia, S.; Kendall, C.W.C.; Bazinet, R.; Hanley, A.J.; Comelli, E.M.; Salas Salvado, J.; Jenkins, D.J.A.; Sievenpiper, J.L. Are fatty nuts a weight concern? A systematic review and meta-analysis and dose-response metaregression of prospective cohorts and randomized controlled trials. Obes. Rev. 2021, 22, e13330-e13347. [CrossRef]

36. Vicinanza, R.; Troisi, G.; Cangemi, R.; Ulderico de Martino, M.; Pastori, D.; Bernardini, S.; Crisciotti, F.; Di Violante, F.; Frizza, A.; Cacciafesta, M.; et al. Aging and adherence to the Mediterranean diet: Relationship with cardiometabolic disorders and polypharmacy. J. Nutr. Health Aging 2018, 22, 73-81. [CrossRef]

37. Micek, A.; Godos, J.; Cernigliaro, A.; Cincione, R.I.; Buscemi, S.; Libra, M.; Galvano, F.; Grosso, G. Total nut, tree nut, and peanut consumption and metabolic status in southern Italian adults. Int. J. Environ. Res. Public Health 2021, 18, 1847. [CrossRef]

38. Ministerio de Agricultura, Pesca y Alimentación (MAPA). Informe de Consumo Alimentario en España 2020 [Internet Database]; MAPA: Madrid, Spain, 2021. Available online: https:/ / www.mapa.gob.es/es/alimentacion/temas/consumo-tendencias/informe-anualconsumo-2020_baja-res_tcm30-562704.pdf (accessed on 15 September 2021).

39. Estruch, R.; Ros, E.; Salas-Salvadó, J.; Covas, M.I.; Corella, D.; Arós, F.; Gómez-Gracia, E.; Ruiz-Gutiérrez, V.; Fiol, M.; Lapetra, J.; et al. PREDIMED Study Investigators. Primary prevention of cardiovascular disease with a Mediterranean diet. N. Engl. J. Med. 2013, 368, 1279-1290. [CrossRef]

40. Guallar-Castillón, P.; Pérez, R.F.; López García, E.; León-Muñoz, L.M.; Aguilera, M.T.; Graciani, A.; Gutiérrez-Fisac, J.L.; Banegas, J.R.; Rodríguez-Artalejo, F. Magnitud y manejo del síndrome metabólico en España 2008-2010: Estudio ENRICA. Rev. Española Cardiol. 2014, 67, 367-373. [CrossRef]

41. Ortíz-Rodríguez, M.A.; Yáñez-Velasco, L.; Carnevale, A.; Romero-Hidalgo, S.; Bernal, D.; Aguilar-Salinas, C.; Rojas, R.; Villa, A.; Tur, J.A. Prevalence of metabolic syndrome among elderly Mexicans. Arch. Gerontol. Geriatr. 2017, 73, 288-293. [CrossRef]

42. Shin, D.; Kongpakpaisarn, K.; Bohra, C. Trends in the prevalence of metabolic syndrome and its components in the United States 2007-2014. Int. J. Cardiol. 2018, 259, 216-219. [CrossRef] [PubMed]

43. Farmanfarma, K.K.; Kaykhaei, M.A.; Adineh, H.A.; Mohammadi, M.; Dabiri, S.; Ansari-Moghaddam, A. Prevalence of metabolic syndrome in Iran: A meta-analysis of 69 studies. Diabetes Metab. Syndr. 2019, 13, 792-799. [CrossRef] [PubMed]

44. Metelskaya, V.A.; Shkolnikova, M.A.; Shalnova, S.A.; Andreev, E.M.; Deev, A.D.; Jdanov, D.A.; Shkolnikov, V.M.; Vaupel, J.W. Prevalence, components, correlates of metabolic syndrome (MetS) among elderly Muscovites. Arch. Gerontol. Geriatr. 2012, 55, 231-237. [CrossRef] [PubMed]

45. Fernández-Bergés, D.; Félix-Redondo, F.J.; Lozano, L.; Pérez-Castán, J.F.; Sanz, H.; Cabrera De León, A.; Hidalgo, A.B.; Morcillo, Y.; Tejero, V.; Álvarez-Palacios, P. Prevalencia de síndrome metabólico según las nuevas recomendaciones de la OMS. Estudio HERMEX. Gac. Sanit. 2011, 25, 519-524. [CrossRef]

46. Lee, S.J.; Lee, E.Y.; Lee, J.H.; Kim, J.E.; Kim, K.J.; Rhee, Y.; Kim, H.C.; Youm, Y.; Kim, C.O. Associations of serum 25-hydroxyvitamin D with metabolic syndrome and its components in elderly men and women. The Korean Urban Rural Elderly cohort study. BMC Geriatr. 2019, 19, 102-109. [CrossRef]

47. Yan, Z.; Fan, Y.; Meng, Z.; Huang, C.; Liu, M.; Zhang, Q.; Song, K.; Jia, Q. The relationship between red blood cell distribution width and metabolic syndrome in elderly Chinese: A cross-sectional study. Lipids Health Dis. 2019, 18, 34-42. [CrossRef]

48. Sinha, N.; Bhattacharya, A.; Deshmuskh, P.R.; Panja, T.K.; Yasmin, S.; Arlappa, N. Metabolic syndrome among elderly care-home residents in southern India: A cross-sectional study. WHO South East Asia J. Public Health 2016, 5, 62-69. [CrossRef] 
49. Chimbo-Yung, J.M.; Chuchuca-Cajamarca, Á.J.; Wong, S.; Encalada-Torres, L.E. Metabolic syndrome and physical activity in elderly people from the Ecuadorian highlands. Rev. Salud Publica 2017, 19, 754-759. [CrossRef]

50. Nogueira Saad, M.A.; Pérez Cardoso, G.; Martins, W.D.A.; Coca Velarde, L.G.; da Cruz Filho, R.A. Prevalence of metabolic syndrome in elderly and agreement among four diagnostic criteria. Arq. Bras Cardiol. 2014, 102, 263-269. [CrossRef]

51. Teixeira de Paula, J.A.; Moreira, O.C.; Diniz da Silva, C.; Santos Silva, D.; dos Santos Amorim, P.R. Metabolic syndrome prevalence in elderly of urban and rural communities participants in the HIPERDIA in the city of Coimbra/MG, Brazil. Investig. Educ. Enferm. 2015, 33, 325-333. [CrossRef]

52. Saukkonen, T.; Jokelainen, J.; Timonen, M.; Cederberg, H.; Laakso, M.; Härkönen, P.; Keinänen-Kiukaanniemi, S.; Rajala, U. Prevalence of metabolic syndrome components among the elderly using three different definitions: A cohort study in Finland. Scand. J. Prim. Health Care 2012, 30, 29-34. [CrossRef] [PubMed]

53. Tyrovolas, S.; Chalkias, C.; Morena, M.; Tsiligianni, I.; Zeimbekis, A.; Gotsis, E.; Metallinos, G.; Bountziouka, V.; Polychronopoulos, E.; Lionis, C.; et al. Health care access and prevalence of metabolic syndrome among elders living in high-altitude areas of the Mediterranean islands: The MEDIS study. Rev. Diabet. Stud. 2011, 8, 468-476. [CrossRef] [PubMed]

54. Fernández-Bergés, D.; Cabrera de León, A.; Sanz, H.; Elosua, R.; Guembe, M.J.; Almazora, M.; Vega-Alonso, T.; Félix-Redondo, F.J.; Ortíz-Marrón, H.; Rigo, F.; et al. Síndrome metabólico en España: Prevalencia y riesgo coronario asociado a la definición armonizada y a la propuesta por la OMS. Estudio DARIOS. Rev. Esp. Cardiol. 2012, 65, 241-248. [CrossRef]

55. Vernay, M.; Salanave, B.; de Peretti, C.; Druet, C.; Malon, A.; Deschamps, V.; Hercberg, S.; Castetbon, K. Metabolic syndrome and socioeconomic status in France: The French Nutrition and Health Survey (ENNS, 2006-2007). Int. J. Public Health 2013, 58, 855-864. [CrossRef]

56. Slagter, S.N.; Van Waateringe, R.P.; Van Beek, A.P.; Van der Klauw, M.M.; Wolffenbutel, B.H.R.; Van Vliet-Ostaptchouk, J.V. Sex, BMI and age differences in metabolic síndrome: The Dutch Lifelines Cohort Study. Endocr. Connect. 2017, 6, 278-288. [CrossRef] [PubMed]

57. Santilli, F.; D'Ardes, D.; Guagnano, M.T.; Davi, G. Metabolic syndrome: Sex-related cardiovascular risk and therapeutic approach. Curr. Med. Chem. 2017, 24, 2602-2627. [CrossRef] [PubMed]

58. Lee, C.G.; Carr, M.C.; Murdoch, S.J.; Mitchell, E.; Woods, N.F.; Wener, M.H.; Chandler, W.L.; Boyko, E.J.; Brunzell, J.D. Adipokines, inflammation, and visceral adiposity across the menopausal transition: A prospective study. J. Clin. Endocrinol. Metab. 2009, 94, 1104-1110. [CrossRef] [PubMed]

59. Smith, U. Abdominal obesity: A marker of ectopic fat accumulation. J. Clin. Investig. 2015, 125, 1790-1792. [CrossRef] [PubMed]

60. Pucci, G.; Alcidi, R.; Tap, L.; Battista, F.; Mattace-Raso, F.; Schillaci, G. Sex- and gender-related prevalence, cardiovascular risk and therapeutic approach in metabolic syndrome: A review of the literature. Pharmacol. Res. 2017, 120, 34-42. [CrossRef]

61. Christakis, N.A.; Fowler, J.M. The spread of obesity in a large social network over 32 years. N. Engl. J. Med. 2007, 357, 370-379. [CrossRef]

62. Yu, Z.M.; Parker, L.; Dummer, T.J. Depressive symptoms, diet quality, physical activity, and composition among populations in Nova Scotia, Canada: Report from the Atlantic Partnership for Tomorrow's Health. Prev. Med. 2014, 61, 106-113. [CrossRef] [PubMed]

63. Ibarrola-Jurado, N.; Guasch-Ferré, M.; Ros, E.; Martínez-González, M.A.; Corella, D.; Fiol, M.; Wärnberg, J.; Estruch, R.; Román, P.; Arós, F.; et al. Cross-sectional assessment of nut consumption and obesity, metabolic syndrome and other cardiometabolic risk factors: The PREDIMED study. PLoS ONE 2013, 8, e57367. [CrossRef] [PubMed]

64. Fernández-Montero, A.; Bes-Rastrollo, M.; Beunza, J.J.; Barrio-López, M.T.; de la Fuente-Arrillaga, C.; Moreno-Galarraga, I.; Martínez-González, M.A. Nut consumption and incidence of metabolic syndrome after 6-year follow-up: The SUN (Seguimiento Universidad de Navarra, University of Navarra Follow-up) cohort. Public Health Nutr. 2013, 16, 2064-2072. [CrossRef] [PubMed]

65. Hosseinpour-Niazi, S.; Hosseini, S.; Mirmiran, P.; Azizi, F. Prospective study of nut consumption and incidence of metabolic syndrome: Tehran lipid and glucose study. Nutrients 2017, 9, 1056. [CrossRef] [PubMed]

66. Hassannejad, R.; Mohamadifard, N.; Kazemi, I.; Manourian, M.; Sadeghi, M.; Roohafza, H.; Sarrafzadegan, N. Long-term nuts intake and metabolic syndrome: A 13-year longitudinal population-based study. Clin. Nutr. 2019, 38, 1246-1252. [CrossRef]

67. Estruch, R.; Martínez-González, M.A.; Corella, D.; Salas-Salvadó, J.; Fitó, M.; Chiva-Blanch, G.; Chiva-Blanch, G.; Fiol, M.; Gómez-Gracia, E.; Arós, F.; et al. Effect of a high-fat Mediterranean diet on bodyweight and waist circumference: A prespecified secondary outcomes analysis of the PREDIMED randomised controlled trial. Lancet Diabetes Endocrinol. 2019, 7, e6-e17. [CrossRef]

68. Vadivel, V.; Kunyanga, C.N.; Biesalski, H.K. Health benefits of nut consumption with special reference to body weight control. Nutrition 2012, 28, 1089-1097. [CrossRef]

69. Kim, Y.; Keogh, J.; Clifton, P.M. Nuts and cardio-metabolic disease: A review of meta-analyses. Nutrients 2018, 10, 1935. [CrossRef]

70. Landsberg, L.; Aronne, L.J.; Beilin, L.J.; Burke, V.; Igel, L.I.; Lloyd-Jones, D.; Sowers, J. Obesity-related hypertension: Pathogenesis, cardiovascular risk, and treatment: A position paper of the Obesity Society and the American Society of Hypertension. J. Clin. Hypertens 2013, 15, 14-33. [CrossRef]

71. Del Gobbo, L.C.; Falk, M.C.; Feldman, R.; Lewis, K.; Mozaffarian, D. Effects of tree nuts on blood lipids, apolipoproteins, and blood pressure: Systematic review, meta-analyisis, and dose-response of 61 controlled intervention trials. Am. J. Clin. Nutr. 2015, 102, 1347-1356. [CrossRef] 
72. Asghari, G.; Ghorbani, Z.; Mirmiran, P.; Azizi, F. Nut consumption is associated with lower incidence of type 2 diabetes: The Tehran Lipid and Glucose Study. Diabetes Metab. 2017, 43, 18-24. [CrossRef] [PubMed]

73. O’Mahoney, L.L.; Mattu, J.; Price, O.J.; Birch, K.M.; Ajjan, R.A.; Farrar, D.; Tapp, R.; West, D.J.; Deighton, K.; Campbell, M.D. Omega-3 polyunsaturated fatty acid favourably modulate cardiometabolic biomarkers in type 2 diabetes: A meta-analysis and meta-regression of randomized controlled trials. Cardiovasc. Diabetol. 2018, 17, 98. [CrossRef] [PubMed] 